\title{
Decentralization and Its Influence in Determining the Direction of Public Policy as an Effort to Improve Community Welfare
}

\author{
Rahmat Salam ${ }^{1}$, Izzatusholekha ${ }^{2}$ \\ ${ }^{1,2}$ University of Muhammadiyah Jakarta, Indonesia \\ Email: rahmat.salam@umi.ac.id
}

\begin{abstract}
Since the fall of the New Order, the Indonesian government has moved towards a decentralized system of government. The Central Government makes policies that provide the widest possible opportunity for local governments to manage their households in order to improve welfare. This study will present an analysis of the implementation and impact of public policies made by local governments, whether they succeed or fail in their implementation, especially to improve the welfare of the community. This study also describes several alternative ways to solve problems related to policy implementation. This research is qualitative in nature using literature study methods to collect data and analyze it.
\end{abstract}

Keywords: Effectiveness of Policy Implementation, Decentralization.

\section{A. INTRODUCTION}

After the reformation, seen from a public policy perspective, the government administration in Indonesia moved towards decentralization. This is an effort to realize equitable development in the regions in the context of equal distribution of welfare for all Indonesian people (Simanjuntak, 2015; Kusuma, 2016).

Regional development is an integral part of national development. Because growth in the regions becomes one of the indicators or supports for the realization of national development. Therefore, the central government makes a policy on regional government in which local governments are given broad authority to regulate their households (Zahara \& Bilouseac, 2009).

By granting broad autonomy to the regions, it is hoped that the realization of community welfare will be accelerated through improved services, empowerment, and community participation (Isufaj, 2014). Also, through broad regional autonomy, it is hoped that it will be able to increase competitiveness by taking into account the principles of democracy, equity, justice, privileges, and specialties and the potential and diversity of the region (Katorobo, 2004).

Of the many definitions of decentralization, it is agreed that the essence of devolution is the transfer of authority and functions from the national government to sub-national governments or independent institutions. The basic idea of decentralization is the division of authority in decision-making in organizations with lower levels (Pugh \& Pugh, 1971). That is, when decision making is carried out only by a group of leaders in an organization, including in-state organizations, it is 
considered centralized. Meanwhile, when decision making is left to lower organizational units, it is deemed to be decentralized.

Decentralization as the context for governance in Indonesia is considered appropriate with the assumption that government organizations at the lower level (local government) know better about the actual conditions and needs of local communities. It is also impossible for the government at the national level to serve and manage all the interests and affairs of the community (Bjork, 2003). Even by some experts, decentralization is also seen as a positive response to democratization's enormous demands. Local governments are expected to be more creative, innovative, and responsive than the central government to local communities' various needs (Haris, 2005).

Regional autonomy and decentralization that have been effective since 2001 are strategic steps for the Indonesian nation to welcome the era of economic globalization by strengthening the regional economy's base. The consequence is the delegation of authority, followed by budget allocation and public goods provision to local governments. Halim (2001) explains that the main characteristic of a region capable of implementing autonomy and decentralization is (1) regional financial capacity, meaning that areas must have the authority and ability to explore financial resources, manage and use their finances are sufficient to finance. The administration of government, and (2) the dependence on central assistance must be as minimal as possible so that local revenue can become a significant source of finance. The role of regional governments becomes bigger. In the implementation of decentralization, the part of transfers is unavoidable, considering that the autonomy delegated requires regions to complete various government affairs that fall under regional authority.

This variant of motivation for decentralization of governance in Indonesia is, of course, inseparable from the views of Ahmad et al. (2005), namely in the context of economic and political transformation (learning from Central and Eastern Europe, Russia); political crises due to ethnic conflicts, such as in Bosnia-Herzegovina; overcoming political problems due to regional conflicts as happened in Indonesia and Madagascar, Mali; efforts to increase public participation by emulating best practice in Argentina, Brazil, Bolivia; political maneuvers such as those that occurred in Peru and Pakistan; fiscal crises, as we have experienced in our country and Russia or Pakistan; increasing public service delivery as the primary motivation for all countries, including in Chile, Uganda, Cote D'Ivoire; as well as to strengthen the pattern of centralization that has happened in China, Turkey, and the European Union. Another motivation is the change in responsibility for adjusting unwanted programs, as has happened in Africa; to prevent the return of authoritarian rule such as the case in Latin America; maintain communist rule, as experienced in China; and, of course, in response to globalization and the information revolution. This last point seems to follow most countries' primary motivation in the world, including Indonesia today.

Learning from the successful experiences of other countries and referring to the national development goals that have been announced since the previous 
government order, the purpose of decentralization of government in Indonesia also refers to the view of Newman (2000), that decentralization is: 1) a national development instrument, 2 ) pillars accompanying democratization, 3) freedom, 4) administrative efficiency, 5) social and economic development, and 6) conflict between objectives and priority scales.

Based on Ahmad views and learning from Newman view above, actually decentralization of government in Indonesia is more specific, by looking at indicators of the effectiveness of implementation and the impact of public policy in development, as stated by Prasodjo \& Kurniawan (2008), it can be noted that : 1) decentralization of governance marked by the implementation of the Law on Regional Government with the aim of reducing central government interference in minor problems at the regional level; 2) the concept of community-based development which is manifested through the Deliberation Development Planning (Musrenbang) mechanism at various levels - village / output to the national level although still criticized, in principle it has good intentions to increase the understanding and support of the people in social development business activities economy; 3) the results of these musrenbang efforts are in principle none other than an attempt to formulate a more realistic socio-economic improvement program at the regional level; and 4) various policies for community empowerment programs, including programs such as IDT, PPK, PNPM Mandiri, CDD (Community Development Driven) aimed at providing policy learning and training people to manage their own affairs and foster national unity within the framework of the Unitary State of the Republic of Indonesia ( NKRI).

\section{B. METHOD}

This study uses a qualitative research design using a descriptive method (Creswell, 2017). This method is intended to describe or describe existing phenomena, both natural phenomena or phenomena that are human engineering. This approach's choice is based on the consideration that the data used What you want to look for is data that explains how the implementation of public policies in this era of autonomy and decentralization can work effectively.

Creswell's view that the researcher chose as an approach in qualitative research is generally the same as Bungin (2015), which explains that qualitative research emphasizes the process aspect rather than just results. According to him, qualitative research has a natural field as a direct data source to be naturalistic. This opinion is also not much different from that conveyed by Sugiyono (2017), citing the statement of Erickson and Susan Stainback (2003) explaining that the characteristic of qualitative research is that this research is carried out intensively, the researcher participates in long participation in the field, notes carefully what happened, conducting a reflective analysis of various documents found in the area and producing detailed research reports. 


\section{RESULT AND DISCUSSION}

According to Lascoumes \& Le Galès (2007) and several experts, it has been questioned why the government often does not know the policies that have been made and implemented from an early age. Negara (2008) responded to Lascoumes \& Le Galès rhetorical question by stating that there were indeed several problems faced in the policy evaluation study, which was later described as policy experimentation.

Several programs and policies have more symbolic value. According to Negara (2008), the symbolic value of a program or policy certainly exists as a guide for its practical value. This is obvious because the two dimensions of value are like two sides of a rolling coin. The symbolic value of these programs and policies does not change the conditions of the target group. Still, it can make the group feel that the government is consistent and "pays attention" to its people's interests.

Government agencies have a strong vested interest in "trying" whether the program has a positive impact. This permanent interest exists in every policy because, according to Purwanto (2012), policy decisions themselves are born from a political process, which often runs tough. To prove this assumption, administrators often perform experiments to evaluate the impact of programs designed as if trying to limit or damage the program or question administrators' competence. Government agencies usually have large organizational, financial, physical, and psychological investments in current programs and policies. It has even become common to understand that public policy actors invest more than just a form of corporate, financial, physical, and psychological investment, but also need to develop investment in human resources because human capital is the most valuable organizational asset.

Some empirical studies on the impact of policies carried out by government agencies have experienced various obstacles or disruptions

on ongoing program activities. Obstacles and challenges, of course, exist as part of the external environment that affects policy implementation. The author agrees with Purwanto (2012) writing, who understands that the more serious obstacles and challenges come from within the implementing organization, such as apathy and inconsistency of actors in acting outside of the collective agreement.

Program evaluation requires funding, facilities, time, and personnel, which government agencies do not want to make sacrifices from an ongoing program. Policy implementation and impact studies, like any number of studies, cost money to finance. The course cannot be adequately conducted as an extracurricular or parttime activity. Setting up resources for the study means sacrificing program resources that administrators do not want to be redundant or inefficient. This means that the activities carried out need to take into account the benefit costs, including the social values that will be borne by the implementers and the policy target group.

In addition to the skeptical responses above, government administrators and policy implementation supporters think of various ways to explain why the negative impact findings of policy should be rejected. Likewise, when facing empirical evidence when a seeded program is useless or counter-productive, the party states: 
1. Program effects are long-term and cannot be measured at present. A policy that is long term is often considered to have lost its practical value. This, according to some people, is the same as the effect of an educational program being implemented, with the assumption that: when expecting results in a short time, plant corn (remember the term "as long as corn"), when expecting results in a few years plant ahead tree (remember the myth that there was a tree. coconut that grows on the beach), but when expecting results in the future, then instill education (human investment), so that it makes people aware that education is the foundation of our progress today and in the future.

2. The program's effects are pervasive and general; therefore, there is no single criterion or suitability index that can be used to measure what was achieved. Policy multiplier effect analysis is one of the analytical approaches commonly used, depending on the carefulness of policy analysts in calculating various appropriate criteria to be used as indicators.

3. Program effects are unclear and cannot be identified by crude or statistical measures. This is logical to understand because not all policy programs implemented must be measured roughly and in the form of numbers (quantitative), but there are also programs or policies whose effects are qualitative, such as policy objectives in the health sector, the effect is not just making the community healthy because they are avoided from illness and longevity (life expectancy increases), but more than that so that people can "behave healthily" or "healthy in thinking" and "think healthy" to ensure unity, progress, and the common good in this beloved country.

4. The fact that there is no difference between those who receive services and those who do not mean that the program is not intensive and indicates the need to spend more resources on the implementation of the program. What needs to be understood is that one of the characteristics of development program policies is sustainable and synergistic, so what needs to be paid attention to is optimizing the use of existing resources by coordinating with other programs that have the same goals or objects.

5. Failure to identify some of the program's positive effects can indicate discrepancies or bias in research, not in the program. The positive impact of a program can generate positive "externalities" for various interested parties. Therefore, all parties need to be careful and appreciative in calculating the positive externalities of the implemented program policies, including learning about implementing policies that occur.

The response to such theorists and practitioners' skepticism can be understood because there are differences and tangible evidence that can be understood based on the implementation and impact of theoretical and practical public policies as follows. According to Purwanto (2012), who commented on the opinions of experts, it was stated that when the policy has been made, the policy must be implemented and the results are following what is expected by the 
policymaker. If visualized, it will be seen that a policy has clear objectives as a perspective and policy value orientation. The objectives of policy implementation are formulated into specific programs of action and projects designed and financed. The program is implemented according to the plan. The implementation of policies or programs - in broad terms - is influenced by the content of the policy and the context of implementation, to quote Merilee $S$ Grindle. Overall policy implementation is evaluated by measuring program output based on policy objectives. The program's result is seen through its impact on the intended targets, both individuals and groups, and the community. The output of policy implementation is change and acceptance of change by both target groups and nontarget groups.

According to the author, many policies implemented in this country are often deemed ineffective only because of differences in perceptions in assessing their impact on target groups, even though the implementation of these policies has resulted in changes in people's attitudes and behavior, as stated above. According to Grindle (1980), what is needed is the configuration and synergy of three variables that determine the success of implementing a policy or program, namely the triangular relationship of policy variables, organization, and the policy environment. This hope needs to be realized so that through selecting the right policies the public can participate in making an optimal contribution to achieving the stated goals. Furthermore, when the selected policy has been found, the implementing organization needs to be accommodated because there are authorities and various types of resources that support the implementation of the policy or program. Meanwhile, creating a situation and condition of the policy environment is necessary to effect, even though the influence is often positive or negative. Therefore, it is assumed that if the environment (society) has a complementary view of policy, it will generate positive support (participation) so that the environment affects the success (effectiveness) of policy implementation.

Conversely, suppose the environment has an opposing view. In that case, there will be a clash of attitudes (conflict) so that the implementation process is threatened with failure, such as the phenomenon of war that has hit our country recently. More than these three aspects, it is also necessary to maintain compliance with policy target groups due to the implementation of policies that determine their effects on society. In short, the effectiveness of policy implementation is based on the community's appreciation (acceptance) and what should not be forgotten is an accountable government.

Based on the above views, the implementation and impact of policies are needed to see the policy target groups' acceptability. Therefore, from the perspective of behavior, compliance, and acceptance of target groups are essential factors determining policy implementation's success.

Encouragement and coercion at the central level are determined by legitimacy and credibility; that is, the more valid policies issued by the central government in the regions' eyes, the greater their credibility, and vice versa. To measure the 
strength of the content or substance and message of the policy, it can be seen through 1) the number of funds allocated efficiently, assuming that the greater the allocated funds, the more seriously the policy is implemented, and 2) the form of the policy which includes, among others, the clarity of the policy, consistency of implementation, frequency of implementation and receipt of messages correctly. Meanwhile, to determine the variable of central capacity or organizational capacity, it can be seen through how far the implementing organization can take advantage of the opportunities and powers it has, how the relationship between the implementer and the bureaucratic structure is, and how to coordinate the various resources available within the organization and in society.

Policy impact is the overall effect of policy in real-life conditions Lascoumes \& Le Galès (2007). According to Lascoumes \& Le Galès, all forms of benefits and costs of the system, both direct and future, must be measured in symbolic effects or tangible effects. Policy output is the various things that are done by the government. For example, construction and rehabilitation of roads and bridges, payment of welfare allowances, or professional allowances, including certified professional teacher allowances, the arrest of criminals and KKN (corruption, collusion, and nepotism), or running public schools (free schools). The measure used is expenditure "per capita" for roads, welfare, handling of crime per 100,000 population, public school attendance, etc. Specific standards measure these activities. The figures that appear only provide little information about the outcome or impact of public policy. To determine the public policy's effect, it is necessary to pay attention to changes in the political environment or system caused by political action. Knowledge of the number of funds per capita used for students in the school system or other cases cannot provide information on the effects of schooling on students' cognitive, affective, and psychometric abilities.

Referring to experts' views, there are several policy impacts (benefits) that need to be considered in policy evaluation, as follows.

The impact of the policy on the situation or target group. The objects referred to as policy targets must be clear, such as the low, small entrepreneurs, disadvantaged school children, or the targets. The effect aimed at by the policy must also be determined. When these different combinations of objectives focus, the analysis becomes more complicated, as priority must be given to the various effects in question. More than that, it needs to be understood that policy is likely to have desirable or undesirable consequences, such as a government policy decision to raise fuel prices whose spirit is to learn from society to live economically or efficiently and support energy-saving programs, but it is understood differently. The facts presented below may be examined further, where it is involved that the implications of poverty alleviation policies targeting the poor in various parts of Indonesia are clear evidence. The policy implications are evident, for example, through the success of the program in developing productive economic activities for the poor, easy access for the community to (revolving) loans, access to markets, including easy access to public services and the improvement in the quality of life of the community 
after the program is implemented. The quality of community life can be seen from social facilities, infrastructure and facilities, education, environmental factors, political representation (rights), and other needs.

The impact of the policy on situations or groups other than the situation or target group. This is called an externality or spillover effect because several public policy outcomes are significant to be understood in terms of externalities. The fact is that the IDT, KDP, PNPM policies, for example, have involved (directly and indirectly) various parties, including government, employers, local government officials, community leaders, teachers and health educators, contractors, etc.

The impact of the policy on current and future conditions. The fact is that the effects of IDT, PPK, and PNPM policies have strengthened the foundations of a populist economy and the poor's independence in particular and society in general. It can even be said that this policy's positive impact has confirmed the desire of the people to respond to the idea of regional autonomy.

Direct policy costs, in the form of resources and funds (money) that have been used in the program. The fact is that various funding agencies have realized their programs. This is logical and in line with poverty alleviation programs financed by multiple parties, including countries that have colonized us (the Netherlands, UK) and donor agencies such as the World Bank, UNDP, AUSAID, USAID, funds from the central government and local governments.

Indirect costs of the policy, which include lost opportunities carry out other activities because of community rejection in demonstrations and rallies. These costs are often not considered in conducting policy evaluations because some cannot or do not want to be quantified. The fact is that it cannot be denied that the policy program implemented will involve various parties whose involvement prevents other activities, for example, children and family members from poor communities who used to help with parental activities must be in school to study at certain hours, employees or employees who join the demonstration cannot work during working hours. This means that the opportunity to help their parents do is lost or reduced. The opportunity for employees to develop professionalism and work productivity is taken up for counter-productive activities.

Of course, it is also difficult to measure the policy's indirect benefits to the communities that a policy program addresses. This can be seen from the symbolic impact of policies, for example, in the education sector seen from changes in attitudes and behavior of citizens to become aware of the importance of education or in the health sector through intelligent attitudes and behavior, as well as behaving and "thinking healthy."

The internal economic impact analysis of policies sponsored by national and international funding agencies is clear evidence and an answer to this skepticism. Therefore, all kinds of effects that are a consequence of a policy, whether symbolic or material, on one or several target groups are the essence that characterizes the impact of public policy. This is following Grindle (1980) opinion that policy evaluation is an activity that aims to assess the benefits of the policy. Policy 
evaluation is an activity that involves estimating or estimating and evaluating policies, which include their substance, implementation, and impact.

\section{CONCLUSION}

Professor James Q. Wilson's two general laws need to serve as a reflection for those of us who will research or examine the impact of policy on social science. Wilson's first law is that all policy interventions on social issues produce the desired effect - if the research is carried out by the person implementing the policy (posterior perception). Wilson's second law is that no policy intervention on social issues produces the desired effect - if the research is conducted by an independent third party, let alone a party who is skeptical or a priori about the policy. For the author, as an observer who is interested in examining the impact of public policy, of course, he positions himself as an advocate of the two general laws of Qilson. Furthermore, socializing and implementing policies that have been formulated to have the expected impact.

\section{REFERENCES}

1. Ahmad, J., Devarajan, S., Khemani, S., \& Shah, S. (2005). Decentralization and Service Delivery. The World Bank.

2. Bjork, C. (2003). Local responses to decentralization policy in Indonesia. Comparative Education Review, 47(2), 184-216.

3. Bungin, H. (2015). Penelitian Kualitatif. Jakarta: Kencana Prenada Media Group.

4. Creswell, J.W. (2017). Research Design. Yogyakarta: Pustaka Pelajar.

5. Grindle, M. S. (1980). Policy content and context in implementation. Politics and policy implementation in the Third World, 3-34.

6. Halim, A. (2001). Anggaran Daerah dan "Fiscal Stress"(Sebuah Studi Kasus pada Anggaran Daerah Provinsi di Indonesia). Journal of Indonesian Economy and Business, 16(4).

7. Haris, S. (2005). Desentralisasi dan Otonomi Daerah: Desentralisasi, Demokratisasi $\mathcal{E}$ Akuntabilitas Pemerintahan Daerah. Jakarta: Yayasan Obor Indonesia.

8. Isufaj, M. (2014). Decentralization and Increased autonomy in Local Governments. Procedia-Social and Behavioral Sciences, 109, 459-463.

9. Katorobo, J. (2005). Decentralization and local autonomy for participatory democracy. In Global Forum on Reinventing Government towards Participatory and Transparency ( $p p$. 24-27).

10. Kusuma, H. (2016). Desentralisasi Fiskal dan Pertumbuhan Ekonomi di Indonesia. Desentralisasi Fiskal dan Pertumbuhan Ekonomi di Indonesia, 9(1), 1-11.

11. Lascoumes, P., \& Le Galès, P. (2007). Introduction: understanding public policy through its instruments - from the nature of devices to the sociology of public policy instrumentation. Governance, 20(1), 1-21.

12. Newman, P. (2000). Changing patterns of regional governance in the EU. Urban Studies, 37(5-6), 895-908. 
13. Prasojo, E., \& Kurniawan, T. (2008). Reformasi Birokrasi dan Good Governance: Kasus Best Practices dari Sejumlah Daerah di Indonesia. In The 5th International Symposium of Journal Antropologi Indonesia.

14. Pugh, D. S., \& Pugh, D. S. (1971). Organization theory: Selected readings (Vol. 126). Harmondsworth: Penguin.

15. Purwanto, E. A. (2012). Implementasi Kebijakan Publik: Konsep dan Aplikasinya di Indonesia. Yogyakarta: Gava Media.

16. Rumbach, A. (2016). Decentralization and small cities: Towards more effective urban disaster governance?. Habitat International, 52, 35-42.

17. Simanjuntak, K. M. (2015). Implementasi Kebijakan Desentralisasi Pemerintahan di Indonesia. Jurnal Bina Praja: Journal of Home Affairs Governance, 7(2), 111-130.

18. Sugiyono. (2017). Metode Penelitian Kualitatif. Bandung: Alfabeta.

19. Zaharia, P., \& Bilouseac, I. (2009). Decentralization and local autonomy-local public management defining principles. Annales Universitatis Apulensis: Series Oeconomica, 11(2), 805. 